\title{
TRANSCONTINENTAL COALITIONS \\ IN THE WORLD ECONOMY
}

\section{ТРАНСКОНТИНЕНТАЛЬНІ КОАЛІЦЇ̈ \\ У СВІТОВОМУ ГОСПОДАРСТВІ}

\author{
Svitlana Radziyevska ${ }^{1}$
}

DOI: https://doi.org/10.30525/978-9934-588-53-2-11

Abstract. The author introduces the concept of the transcontinental coalition as the new one in the system of concepts used for the analysis of the world economy. Transcontinental coalition is viewed as a transregional coalition in which the region is a continent; transcontinental coalition may be formed by states, regional groups, organizations, associations, individuals, etc. or the organizations in various formats formed by them in case the members are located on two or more continents. The nature of the relations between the members forming the transcontinental coalition is determined by them and may be of either the institutional character or the non-institutional, advisory, informational character. The formation of transcontinental coalitions allows to expand the composition of its participants in order to take important decisions for the development of the world economy, to deeply and comprehensively examine various situations in it, and ideally to carry out the decisions that take into account and further realize the interests of all or at least most members of the transcontinental coalition.

Transcontinental coalitions are the subjects of the transregional level, which is located between the regional and the global level in the structure of the world economy. The methodology of the research is based on the analysis of the theoretical aspects of transcontinental coalitions, followed by the practical application of the arrived conclusions to the peculiarities of the current state of the formation and functioning of these coalitions in the world economy.

The publication touches upon the Asia-Pacific Economic Cooperation (APEC) and the more developed transcontinental coalitions - the

\footnotetext{
${ }^{1}$ Candidate of Economic Sciences, Associate Professor, National Academy of Management, Ukraine

(C) Svitlana Radziyevska
} 
Transatlantic Trade and Investment Partnership (TTIP) and the Regional Comprehensive Economic Partnership (RCEP) - which are both aimed at signing the trade deals in 2020, as well as the most developed coalition Comprehensive and Progressive Agreement for Trans-Pacific Partnership (CPTPP) with already signed free trade agreement in 2018. The APEC phenomenon shows that in order to influence the development of the world economy, a transcontinental coalition must conclude certain agreements by its members to ensure their collective actions. The paper gives the analysis, on the one hand, of the TTIP as a perspective transcontinental coalition, striving to sign the free trade agreement between the USA and the EU with the purpose of strengthening their joint impact on the world economy in the form of the Euro-Atlantic Center of economic influence, introduced by the USA, and, on the other hand, of the RCEP as the coalition pushing the interests of the Eastern enclave of economic power, along with the transcontinental network "One belt, one road", initiated by China.

The novelty of the work is, firstly, the introduction of the concept of the transcontinental coalition to reveal the ambitions of the Euro-Atlantic center of economic influence and those of the Eastern enclave of economic power, and, secondly, the elaboration of the suggested algorithm for successful future of the world economy which is based on the principle of gradual development of transcontinental coalitions and progressive strengthening of the coherence of their coordination on its basis.

\section{1. Ветуп}

Особливістю розвитку процесів глобалізації та регіоналізації у світовому господарстві наприкінці XX ст. - на початку XXI ст. $є$ формування трансрегіональних і трансконтинентальних коаліцій, функціонування яких виходять за межі одного континенту чи регіону, охоплюючи два і більше континенти і регіони, де регіони набувають міжнародного значення, формуючись завдяки взаємодії держав або квазідержавних утворень, внаслідок чого посилюється їхня взаємозалежність, при цьому така взаємодія може виходити і на наднаціональний рівень.

Актуальність теми статті визначається тим, що на сучасному етапі розвитку світового господарства в умовах запровадження здобутків Четвертої індустріальної революції, впровадження швидкісного інтернету, штучного інтелекту і роботизації виробництва, його мережевіза- 
ції та диджиталізації набувають нової специфіки процеси регіоналізації, їх поширення на регіони й континенти, формування і розвиток у світовому господарстві трансконтинентальних коаліцій, доповнення існуючих рівнів структури світового господарства трансрегіональним, який $\epsilon$ ключовим через його потенціал покращення координації і управління світовим господарством.

Теоретичні та практичні аспекти становлення і розвитку трансрегіонального рівня структури світового господарства, який є натепер недостатньо вивченим, у роботі представлений, зокрема, трансконтинентальними коаліціями, серед яких на особливу увагу заслуговують АТЕС, ТТП, ТТІП, РВЕП, трансконтинентальна мережа “Один пояс, один шлях". Актуальності набуває всебічне дослідження сучасного стану формування у світовому господарстві трансконтинентальних коаліцій, розкриття суперечливих аспектів розвитку РВЕП та ТТІП. 3 огляду на вищезазначене у статті вносяться пропозиції, спрямовані на формування алгоритму розвитку трансконтинентальних коаліцій у світовому господарстві для забезпечення його консолідованого узгодженого розвитку.

Мета статті - запропонувати поняття трансконтинентальної коаліції і на прикладі запровадження РВЕП та ТТІП визначити можливі найближчі напрями подальшого розвитку трансконтинентальних коаліцій у світовому господарстві.

\section{2. “Трансрегіоналізація" i “інтеррегіоналізація" у науковій літературі}

У науковій літературі з проблематики формування і розвитку трансконтинентальних коаліцій поряд із терміном "трансрегіоналізація" використовується термін “інтеррегіоналізація”. Існують різні погляди на співвідношення цих двох понять: інтеррегіоналізм визначають як один із видів трансрегіоналізму; при цьому доволі часто обидва терміни використовуються майже синонімічно, в той час як більш популярним у зарубіжних дослідженнях є термін “інтеррегіоналізм”. Наприклад, Ю. Рюланд виокремлює двосторонній інтеррегіоналізм (ASEAN-EU, ASEAN-Mercosur, EU-Mercosur) та трансрегіоналізм (ASEM, APEC) i зазначає, що обидва типи взаємодії між регіональними організаціями 3'явилися на початку 1970-х pp. [1, с. 2]. 
На думку одного із найвідоміших дослідників інтеррегіоналізму Х.Хенггі, інтеррегіоналізм тісно пов'язаний із концепцією Тріади, під якою спочатку розуміли відносини між США, СС та Японією. Згодом концепція зазнала розширення, охопивши райони Тріади - Північну Америку, Західну Європу та Східну Азію - внаслідок таких факторів: закінчення «холодної війни», появи «нового регіоналізму» та зміцнення Східної Азії, яка стала третьою складовою Тріади. У 90-х роках було посилено інтеррегіональні зв'язки між регіонами Тріади, і вже до середини 1990-х рр. нова концепція Тріади стала головною особливістю міжнародного порядку, який почав зароджуватися [2, с. 5].

Аналіз наукової літератури засвідчує, що натепер інтеррегіоналізм не $є$ чітко визначеним, хоча існує величезна кількість праць, присвячених вивченню цього феномена [3, с. 4-5]. Домінує думка, що інтеррегіоналізм є інструментом Тріади для підтримування рівноваги між собою, тоді як решта регіонів (що не належать до Тріади) вимушені дотримуватися правил Тріади та встановлювати власні інтеррегіональні відносини, щоб підлаштовуватися під динаміку Тріади [2, с. 9-10; 4; 5, с. 70]. Х.Хенггі, Р.Ролофф, Ю.Рюланд зазначають, що інтеррегіоналізм використовують декілька потужних держав для посилення свого впливу на інші країни [6, с. 34-42]. Отже, інтеррегіоналізм - це прагматична та гнучка реакція гравців, «спрямована проти інших». Інтеррегіоналізм розглядається німецькими вченими Г.В. Молом, Н. Окфеном як один із варіантів кооперації малих чи середніх країн з метою створення коаліцій проти великих держав чи альянсів, що становлять загрозу. Така кооперація має за мету просування інтересів невеликих країн і слугує підтримці рівноваги на міжнародній арені в умовах жорсткої конкуренції [7].

3 одного боку, на думку американців В.К. Агарваль і Е. Фогарті, “трансрегіоналізм" є концептом, який є ширшим за “інтеррегіоналізм” і позначає більше, ніж вузьку взаємодію між двома інституціоналізованими регіонами, як правило, у формалізованому та здебільшого у міжурядовому форматі. 3 другого боку, Ф. Баерт, Т. Скармаглі, $\Phi$. Содербаум вважають, що трансрегіоналізм $є$ вужчим за інтеррегіоналізм і його використовують для позначення інтеррегіональних відносин, в яких задіяні географічно розташовані два або більше регіони, що не представлені розвинутими регіональними організаціями 3 потужним рівнем суб'єктності. 
Можна констатувати, що поряд із термінами “трансрегіоналізм” і “інтеррегіоналізм” науковцями також використовуються синонімічно такі терміни, як “кросрегіоналізм”, “панрегіоналізм”, “макрорегіоналізм”, “мережевий регіоналізм”, “трансконтиненталізм” тощо. При цьому Х. Хенггі виокремлює такі п’ять типів інтеррегіоналізму, а відповідно і п'ять типів утворення інтеррегіональних об'єднань: 1) взаємодія між регіональною організацією чи інтеграційним об'єднанням держав та окремою державою іншого регіону (ОБСЄ-Південна Корея, ЄС-США); 2) взаємодія між двома регіональними інтеграційними об'єднаннями (ЄС-АСЕАН); 3) взаємодія між регіональною організацією чи форумом і регіональною інтеграційною групою (АСЕМ-СС); 4) взаємодія між групами держав двох регіонів (Форум Східноазіатсько-Латиноамериканського партнерства (САЗЛАФ); 5) відносини між окремими державами з різних регіонів світу (ATEC). Другий тип він називає чистим інтеррегіоналізмом, п'ятий - трансрегіоналізмом [8, с. 15-16].

Необхідно брати до уваги, що утворення і розвиток коаліцій передбачає участь в них як окремих держав і регіональних об'єднань, так і міжнародних організацій, інших суб'єктів світового господарства, включаючи особистості, а також будь-які утворені ними організації у різних форматах. Причому переговори між ними і домовленості можуть мати як формальний, інституціональний характер, так і неформальний, тобто епізодичний, нерегулярний, юридично не оформлений відповідно до міжнародного права. При неформальному характері участі держав їх зустрічі та переговори не завершуються юридично оформленими угодами і не передбачають включення у дію механізмів примусу їх виконання. Зустрічі проводяться регулярно, їх результатом стає прийняття заяв та декларацій, водночас слід констатувати велику кількість таких зустрічей [3, с. 10-11]. У дослідженні Ю. Рюланда наведено функції інтер- та трансрегіональних форумів, де виокремлюються такі: 1) забезпечення балансу сил та ефект приєднання до сильного (balancing and bandwagoning), прагматичні та гнучкі коаліції регіональних організацій мають за мету послабити переваги конкурентів та зміцнити свої; 2) інституціоналізація (institution-building); 3) раціоналізація (rationalizing); 4) формування порядку денного та контроль виконання (agenda-setting and -controlling); 5) формування іден- 
тичності (identity-building); 6) забезпечення стабільності (stabilizing); 7) розвиток (development) [1, с. 3-4].

На думку К. Дента, поняття трансрегіоналізму є ширшим за поняття інтеррегіоналізму, й більшість інтеррегіональних конфігурацій мають “потенціал багатосторонньої корисності”, який вчений визначає як проактивний внесок у стабільність, мир, процвітання та рівність у глобальній системі разом із міжнародними інституціями. Поняття “потенціал багатосторонньої корисності” є важливим для розв’язання проблеми кращої координації різних рівнів та типів міжнародних відносин, сприяючи більш конгруентному, гармонійному, кооперативному функціонуванню в глобальній багатосторонній системі [9, с. 214]. Подібної точки зору притримуються Ю. Рюланд, В.К. Агарваль, Е. Фогарті, які пов'язують інтеррегіоналізм з проблемою глобального управління відомі дослідники проблем інтеррегіоналізму впевнені, що інтеррегіоналізм сприятиме інституціоналізації глобальної кооперації та соціалізації гегемонів, яка має залучити їх до співпраці, що перешкоджатиме унілатералізму. Так, вчені вважають, що інтеррегіоналізм інституціоналізуватиме відносини між регіонами, що сприятиме посиленню ролі трансрегіонального рівня, який, знаходячись між глобальним та регіональним рівнями світового господарства, $є$ перспективним щодо вирішення питань, пов'язаних із глобальним управлінням. Інтеррегіоналізм виступає посередником, свого роду вузловим пунктом у багаторівневій системі глобального управління, в якій містяться глобальні інституції, регіональні організації та національні держави. Аналогічно регіональна чи інтеррегіональна домовленість, на думку вчених, $є$ ширшою, ніж двостороння і вужчою, ніж багатостороння, відповідно може заповнити прогалину в управлінні [4, с. 60-68].

На нашу думку, трансрегіональний рівень потенційно $є$ рівнем формування ефективного механізму глобального управління, оскільки на глобальному рівні майже неймовірно дійти консенсусу, а регіональний рівень $є$ занадто обмеженим лише певним регіоном. В свою чергу інтеррегіоналізм базується на багатополярності, яка доповнює багатосторонню систему і $є$ неодмінним елементом світового порядку, який можна охарактеризувати як багаторівневу систему управління [10]. Ю. Рюланд навіть припускає, що науковці мають діяти як радники з політичних питань, наголошуючи на важливості узаконеної та 
інституціоналізованої системи глобального управління [11]. Саме на трансрегіональному рівні, не дивлячись на низький рівень інституціоналізації, країни приймають рішення щодо економічної політики, які впливають на глобальний рівень - прикладом може слугувати як G7, так i G20. Таким чином, інтеррегіоналізм як сфера аналізу міжнародних відносин визначає ці відносини як новий рівень у системі глобального управління [12] або глобальний порядок [6]. Наведені думки стосовно визначення специфіки інтеррегіоналізму і транрегіоналізму підтверджують, що у науковій літературі відсутня єдність щодо визначення процесу утворення коаліцій на рівні регіонів та континентів як інтер- чи трансрегіональних, хоча поступово і тяжіє в бік визнання їх як трансрегіональних чи трансконтинентальних. Та з обох цих визначень є очевидним, що ці коаліції формуються на основі державного макрорівня і метарівня регіональних об'єднань світового господарства і тому можна цей рівень визначити як трансрегіональний на знак того, що він спирається на всі існуючі регіональні об'єднання світового господарства, а не формується двома чи декількома регіональними об'єднаннями.

Вищезазначене означає, що, крім перспектив, які зосереджуються на державі, регіоні чи системі для вирішення міжнародних питань, з'являється все більша кількість авторів, які доводять, що інтеррегіональний рівень є новим, фундаментальним і перспективним для здійснення сучасних аналітичних досліджень в галузі як глобальної, так і регіональної динаміки. Інтеррегіональні відносини є: по-перше, відносинами між країнами, що належать до двох або більше регіонів, також відомі як мегарегіональні або трансрегіональні, i, по-друге, зв'язками між групами або регіональними організаціями та третіми окремими державами, які іноді називають квазі-інтеррегіональними відносинами [6]. Можна підсумувати, що аналіз наукової літератури підтверджує, що координація на трансрегіональному рівні націлена на управління складною взаємозалежністю у багатополярному світі, яка посилюється.

На наш погляд, варто приєднатися до групи вчених, яка розглядає трансрегіоналізацію як процес, що включає інтеррегіоналізацію, оскільки трансрегіоналізація охоплює взаємодію не лише регіонів як у випадку класичного інтеррегіоналізму, але й відносини між найрізно- 
манітнішими суб'єктами світового господарства і передбачає можливість охоплення усіх регіональних об'єднань світового господарства. Процеси трансрегіоналізації ведуть до утворення суб'єктів світового господарства, які узагальнено можна визначити як трансрегіональні спільноти чи трансконтинентальні коаліції. Зауважимо, що поняттям «регіон» може бути визначений і континент. Таким чином, підкреслимо ще раз, що трансрегіональний рівень у структурі світового господарства сформувався через посилення глобальної взаємозалежності та $€$ результатом взаємодії регіонального і глобального рівнів.

\section{3. Азійсько-Тихоокеанське економічне співробітництво}

Особливе місце у світовому господарстві посідає Азіатсько-Тихоокеанський регіон (АТР), який у XXI ст. став третім за величиною центром економічної інтеграції, регіоналізм якого набув глобального значення. АТР, як геополітичний та геоекономічний простір, тривалий історичний період залишався на узбіччі магістральних напрямів світового розвитку, однак саме розпад біполярної системи у 90-ті роки $\mathrm{XX}$ ст. спричинив появу нового центру міжнародного економічного співробітництва, що став ареною міждержавних та міжцивілізаційних суперечностей [13, с. 367-372].

Саме у АТР сформовано першу і найбільшу у світі за простором та обсягом ресурсів трансконтинентальну коаліцію - Азійсько-Тихоокеанське економічне співробітництво (АТЕС) - у 1989 р. в Канберрі за ініціативи Австралії та Нової Зеландії. АТЕС формують країни Євразії (Росія), Азії (Бруней, В’єтнам, Гонконг, Індонезія, Китай, Республіка Корея, Малайзія, Таїланд, Тайвань, Філіппіни, Чилі, Японія) Північної (США, Канада, Мексика) і Південної Америки (Перу, Чилі), Австралії, Нової Зеландії і Папуа-Нової Гвінеї, тобто 19 країн чотирьох континентів, та території Гонконгу і Тайваню. Наведені на рис. 1 у вигляді графиків дані характеризують розвиток АТЕС після першої глобальної кризи як стабільний з незначним підвищенням основних соціально-економічних показників - виробництва номінального ВВП і ВВП на душу населення.

У 2018 р. у порівнянні з 2012 р. ВВП АТЕС зріс на 20,08\%, ВВП на душу населення - збільшився на 15,31\%, а чисельність населення зросла на 4,13\%. Розглянемо динаміку зовнішньоторговельної діяль- 


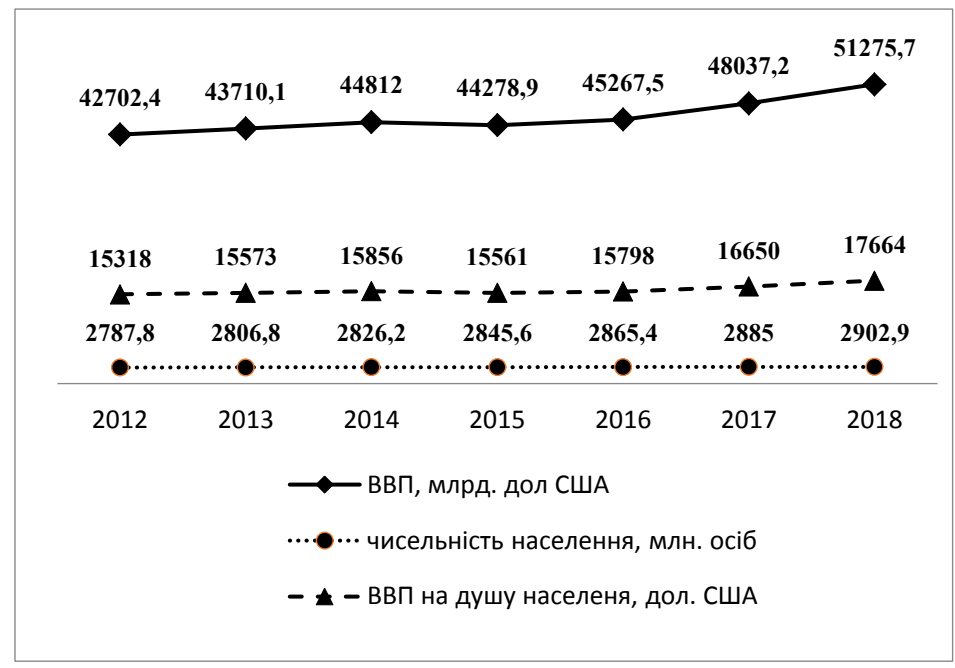

Рис. 1. Динаміка ВВП, чисельності населення та ВВП на душу населення АТЕС, 2012-2018 pp.

Джерело: складено автором за [14]

ності ATEC (рис. 2). Аналіз експорту та імпорту товарів та послуг дозволяє відзначити у якості першої особливості негативне сальдо торгівлі. Другою особливістю є нестабільний їі характер, коли на відрізку часу 2012-2014 pр. спостерігається зростання як експорту, так і імпорту, за яким з 2014 по 2016 рр. і експорт, і імпорт зменшуються із зменшенням інтенсивності падіння у 2015 р. і у 2016 р. знову спостерігається зростання. Розмір негативного сальдо торгівлі товарами i послугами ATEC з максимального у 2012 р. у розмірі 416,3 млрл. дол. США зменшується до мінімального розміру у 45,3 у 2015 р. і знову зростає до 215 млрд. дол. США у 2017 році.

АТЕС є трансконтинентальною коаліцією, яку утворюють держави та економіки, взаємовідносини між якими не є обмеженими будьякими домовленостями - усі переговори мають консультативно-дорадчий, не обов'язковий з точки зору виконання характер. Отже, безперечною умовою подальшого розвитку АТЕС є прийняття на його рівні рішень інституційного характеру. Це у першу чергу ставить питання 


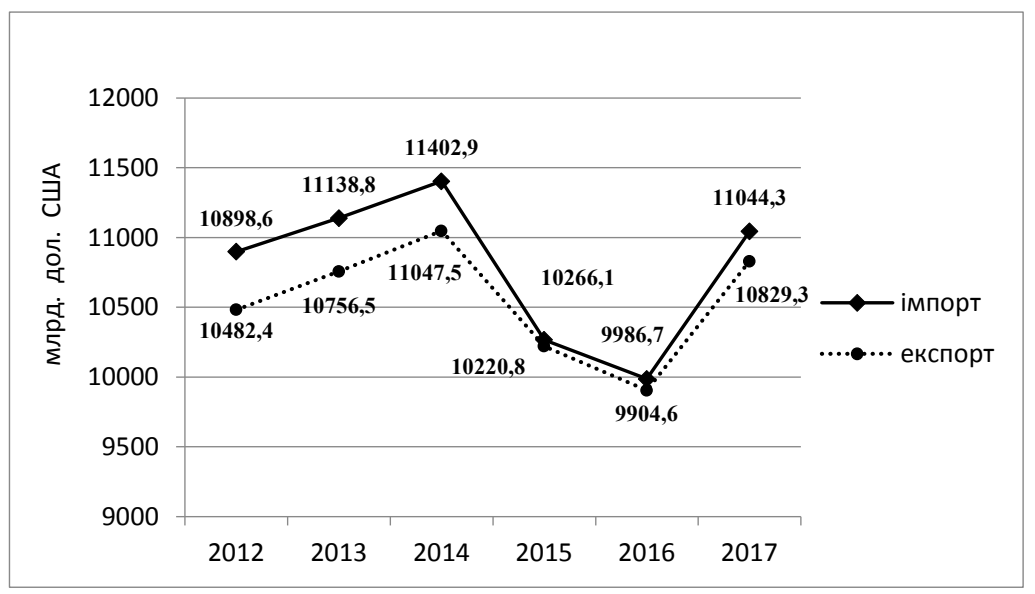

Рис. 2. Динаміка експорту та імпорту товарів і послуг АТЕС у 2012-2018 рр., млн. дол.

Джерело: складено автором за [14]

про набуття ним якості ЗВТ та прийняття рішень, виконання яких стає обов'язковим для усіх членів АТЕС. На нашу думку, АТЕС є феноменом, який виявив можливість утворення трансконтинентальних коаліцій та разом із тим показав, що ефективність використання такого роду коаліцій потребує удосконалення механізму їх функціонування. Тому у подальшому утворення трансконтинентальних коаліцій у світовому господарстві почало приймати форму партнерств і передбачати, як мінімум, утворення ЗВТ.

\section{4. Євро-Атлантичний центр економічного впливу і Східний анклав економічної сили}

Досвід започаткування США Євро-Атлантичного центру економічного впливу свідчить про те, що у його основі знаходилося формування міжнародних економічних організацій. Алгоритм утворення Свро-Атлантичного Центру економічного впливу базувався на послідовному забезпеченні шляхом прийнятих у Бреттон-Вудсі рішень відбудови країн Свропи шляхом сприяння розвитку між ними і США співробітництва, що і дозволило країнам Західної Європи інтегруватися у 
могутній Євросоюз, який разом із США став центром впливу. Значну роль у цьому процесі відіграло утворення єдиної світової фінансової системи. Подальший розвиток Свро-Атлантичного центру передбачає підписання ТТІП, тобто у його основі - трансконтинентальна коаліція у формі партнерства, яка забезпечить утворення між США та країнами ЄС-28 ЗВТ, посилюючи їх інвестиційне співробітництво, що сприятиме подальшому економічному розвитку та впливу на економічні процеси у світовому господарстві. США у торгівлі товарами 3 ЄС мають значне негативне сальдо, а отже вони зацікавлені, зокрема, і у корегуванні торговельно-економічних відносин з СС. 15 квітня 2019 р. згідно з офіційною інформацією Європейської комісії переговори щодо підписання ТТІП, ініційовані здебільшого американською стороною ще у 2013 р., зайшли у глухий кут [15], однак вже 6 лютого 2020 р. Джозеп Боррелл офіційно заявив про наміри СС повернутися до розгляду підписання трансатлантичного партнерства [16]. На наш погляд, подальший розвиток ТТІП після підписання може передбачати зміну складу, розширення кількості учасників з метою поширення впливу Свро-Атлантичного центру на країни насамперед Латинської Америки й Африки. До ТТІП в перспективі можуть бути приєднані ЮСМКА, ЗВТ ЄС-Японія, ЗВТ ЄС-Канада тощо.

В основі утворення трансконтинентальної коаліції РВЕП міститься інший алгоритм, який проявився у послідовній боротьбі КНР шляхом розвитку торговельно-економічних угод з країнами Східної і Південної Азії, а також із Австралією та Новою Зеландією завоювати статус регіонального гегемона. Особливої уваги заслуговує використання КНР трансконтинентальної мережі «Один пояс, один шлях» для посилення Східного анклаву, використовуючи зміцнення ролі юаня у світовій фінансовій системі. Варто погодитися із доктором наук Томасом Едером, старшим дослідником Інституту досліджень Китаю Меркатор у Німеччині, коли він наголошує, що наразі вже стало очевидним, що “Один пояс, один шлях" - це набагато більше, ніж доступ до ринків, забезпечення торгових шляхів та енергопостачання, експорт надмірних потужностей для далеких будівельних проектів, це насамперед ключова частина реалізації великого зовнішньополітичного плану КНР для посилення іiї впливу не лише на регіональному, але і на глобальному рівнях [17]. За п'ять років з моменту запуску проекту КНР інвестувала понад 
70 млрд дол США у інфраструктурні проекти, особливо у виробництво та передачу електроенергії, у цифрову та фінансову інфраструктуру.

Підкреслимо, що у 2017 р. проект було внесено до Конституції Комуністичної партії Китаю, він набув стратегічної пріоритетності. Крім того, проект не обмежується початковими цільовими регіонами вздовж історичних сухопутних та морських шляхів між КНР та $\mathrm{CC}$, його географічна сфера постійно розширюється. Пекін вже вийшов через Арктику до Європи і висловив намір реалізовувати проект у Латинській Америці. Такі вражаючі несподівані результати проекту викликали контр-ініціативи деяких держав, в першу чергу США, а також і регіональних держав, розташованих в Азії та Європі, занепокоєних зростаючим впливом КНР. Японія у 2015 р. презентувала ініціативу "Expanded Partnership for Quality Infrastructure" (Розширене партнерство для якісної інфраструктури), у 2017 р. разом із Індією запустила “Asia-Africa Growth Corridor” (Коридор зростання Азія-Африка). Згодом до Японії та Індії приєдналися США і Австралія для обговорення посилення безпеки у форматі діалогу. ЄС розпрацьовує власні стратегії реагування, Росія висунула інтеграційну концепцію "Greater Eurasia” (Велика Свразія) з метою залучення країн-учасниць СНД, ШОС, навіть потенційно АСЕАН [17].

Узагальнюючи досвід утворення Євро-Атлантичного центру економічного впливу і Східного анклаву економічної сили, відзначимо, що їхнє формування засновано на комплексному використанні тих можливостей, які надавали міжнародна торгівля і світова фінансова система, особливо досягнення національними валютами статусу світових резервних валют. Аналіз розвитку Євро-Атлантичного центру вивів дослідження до рівня утворення ним ТТІП, а розвиток Східного анклаву - до утворення РВЕП - тобто до структур, які формують трансрегіональний рівень, проміжний між регіональним і глобальним. Очевидно, що до глобального управління трансрегіональний рівень значно ближче порівняно з регіональним. Отже, зрозумілим $є$ і конкурентний характер функціонування розглянутих центрів економічного впливу. Подальший розвиток трансрегіональних коаліцій сприятиме при збереженні конкуренції як принципової характеристики ефективності економіки дозволити доповнити ії механізм механізмом угод i цим посилити глобальне управління світовим господарством. 


\section{5. Трансатлантичне торговельне та інвестиційне партнерство і Регіональне всеохоплююче економічне партнерство}

Порівняємо деякі соціально-економічні показники трансконтинентальних коаліцій ТТІП і РВЕП. У науковій літературі вони також отримали назву партнерств, тому що належать до першої інтеграційної стадії, яка містить елементи третьої стадії - створення зон, що регулюються згідно із спільними правилами руху товарів, послуг, частково капіталів, в першу чергу - інвестицій. Партнерства не ставлять за мету створення МС, тобто запровадження єдиної митної політики щодо третіх країн, залишаючи можливості для третіх країн встановлювати відносини різного рівня та різні за форматом з окремими учасниками партнерств [18, с. 12-13].

ТТІП передбачає утворення ЗВТ, що об'єднує найпотужнішу країну США і найрозвиненіше об’єднання $Є С$, метою є посилення СвроАтлантичного центру. Х.Хенггі підкреслює, що відносини між ЄС та США є важливим елементом глобальної інтеррегіональної мережі [2, с. 7]. Одна з головних причин трансконтинентальних відносин ЄС-США - взаємодія для реагування на зовнішні виклики та зміни багаторівневої глобальної структури управління. Необхідно підкреслити, що ТТП та ТТІП мали за мету посилення Свро-Атлантичного центру, в той час як РВЕП, “Один пояс, один шлях" - Східного анклаву. Очевидно, що спочатку ТТП та ТТІП були спроектовані задля зміцнення позицій США насамперед у Східній Азії та АТР. Пригадаємо, що ТТП $\epsilon$ розширенням Транстихоокеанської стратегічної економічної партнерської угоди, яку було підписано 4 країнами - Брунеєм, Чилі, Новою Зеландією та Сінгапуром - у 2005 р., у 2008 р. до неї приєдналися 8 країн, включаючи і США. В жовтні 2015 р. в Атланті було завершено переговорний процес 3 узгодження положень ТТП між 12 країнами. Китай не було включено до цього партнерства. ТТП проектувався в інтересах посилення лідерства США в АТР, однак Д.Трамп виконуючи передвиборчу програму, вивів США з ТТП у січні 2017 року. Після виходу США з ТТП 11 країн - Австралія, Бруней, В’єтнам, Канада, Малайзія, Мексика, Нова Зеландія, Перу, Сінгапур, Чилі, Японія - на основі правил ТТП уклали Всеосяжну та прогресивну угоду про ТТП (Comprehensive and Progressive Agreement for Trans-Pacific Partnership СРТРР), яка набула чинності 30 грудня 2018 року. 
Однак Китай як альтернативу ТТП прийняв активну участь у розробці РВЕП. РВЕП слід розглядати, по-перше, як своєрідний компроміс між ЕАFТА (Східноазіатська ЗВТ) і СЕРЕА (Всеохоплююче східноазіатське економічне партнерство), по-друге, як альтернативу ТТП, де беруть участь не всі члени АCЕАН, по-третє, як інструмент для збереження АСЕАН у ролі локомотива регіональних інтеграційних процесів. На країни РВЕП припадає 70\% всіх угод про вільну торгівлю в Азії. Якщо врахувати, що зона РВЕП може охопити країни світу, де проживає майже половина людства (понад 3 млрд. осіб), виробляється $33 \%$ світового ВВП і реалізується близько $40 \%$ світової торгівлі, потенційно РВЕП може стати найбільшим інтеграційним угрупованням світу [19, с. 313]. Зазначимо, що наразі відносини між КНР та АСЕАН досягли значного успіху, вже пройшло 15 років, після того, як сторонами було укладено угоду про стратегічне партнерство. Китай, по-перше, зробив пропозицію, яка мала значний ефект, поєднавши ініціативу «Один пояс, один шлях», "Бачення АСЕАН 2025" та національні стратегії розвитку країн АСЕАН; по-друге, посилив співробітництво з АСЕАН в галузі безпеки; по-третє, поглибив економічне, торговельне та інвестиційне співробітництво і завершив роботу над набуттям чинності протоколу щодо поглиблення ЗВТ КитайАCЕАН; по-четверте, розширив обмін у сферах, пов'язаних з освітою, туризмом, засобами масової інформації та розвитку молоді; по-п'яте, проголосив Рік інновацій Китай-АСЕАН для поглиблення співпраці у цифровій економіці, штучному інтелекті, Internet Plus тощо. У 2018 р. було прийнято бачення стратегічного партнерства КитайACEAH 2030 [20, с. 95].

Розглянемо більш детально показники РВЕП, який утворений країнами АСЕАН та Австралією, Індією, КНР, Південною Кореєю, Новою Зеландією, Японією, а потім порівняємо його із ТТІП (табл. 1).

Спостерігається значна асиметрія даних (табл. 1), що характеризують обрані трансконтинентальні коаліції, яка проявляється у більш ніж у 4 рази перевищенні чисельності населення РВЕП у порівнянні 3 чисельністю населення ТТІП при майже у 1,5 рази перевищенні номінального ВВП ТТІП і більш ніж у 6 разів перевищенні номінального ВВП ТТІП на душу населення аналогічних показників РВЕП. При цьому експорт товарів країнами РВЕП перевищує імпорт, а країн 
Таблиця 1

Основні соціально-економічні показники РВЕП та ТТІП, 2015-2018 pp.

\begin{tabular}{|l|c|c|}
\hline \multicolumn{1}{|c|}{ Показники } & РВЕП & ТТІП \\
\hline Населення, млн осіб, & 3525 & 833 \\
2015 & 3577 & 836 \\
2016 & 3604 & 838 \\
2017 & 3642 & 844 \\
2018 & & \\
\hline Обсяг номінального ВВП, млрд. дол. & 22712154 & 33993080 \\
2015 & 28284321 & 40374469 \\
2018 & & 40825 \\
\hline ВВП на душу, дол. & 6443,6 & 47831 \\
2015 & 7765 & 40825 \\
2018 & 6443,6 & 29 \\
\hline Обсяг номінального ВВП & 16 & \\
на душу населення, дол.,2015 & & 6892227 \\
\hline Кількість країн-учасниць (2020) & 5084934 & 6830403 \\
\hline Експорт товарів млрд. дол. & 4689668 & 7446853 \\
2015 & 5418089 & 8134333 \\
2016 & 5897457 & 7521050 \\
2017 & & 7504456 \\
2018 & 4497991 & 9022568 \\
\hline Імпорт товарів млрд.дол. & 4279393 & \\
2015 & 4968072 & \\
2016 & 5641774 & \\
2017 & & \\
2018 & & \\
\hline
\end{tabular}

Джерело: розраховано автором за даними [21-24]

ТТІП - менше імпорту. Співставлення чисельності населення і виробленого номінального ВВП РВЕП та ТТІП у 2015 і 2018 рр. дозволяє відзначити, що якщо чисельність населення РВЕП за цей період часу зросла на 3,32\%, то ТТІП - на 1,32\% (рис. 3).

ВВП РВЕП за цей період часу зросло на $24,53 \%$, а ВВП ТТІП - на 18,77\%. Отже, чисельність населення ТТІП зростає повільніше зростання чисельності населення РВЕП, а зростання ВВП РВЕП випереджає зростання ВВП ТТІП. Проте якщо досягнення ТТІП чисельності населення РВЕП неможливе, то РВЕП у перспективі може 


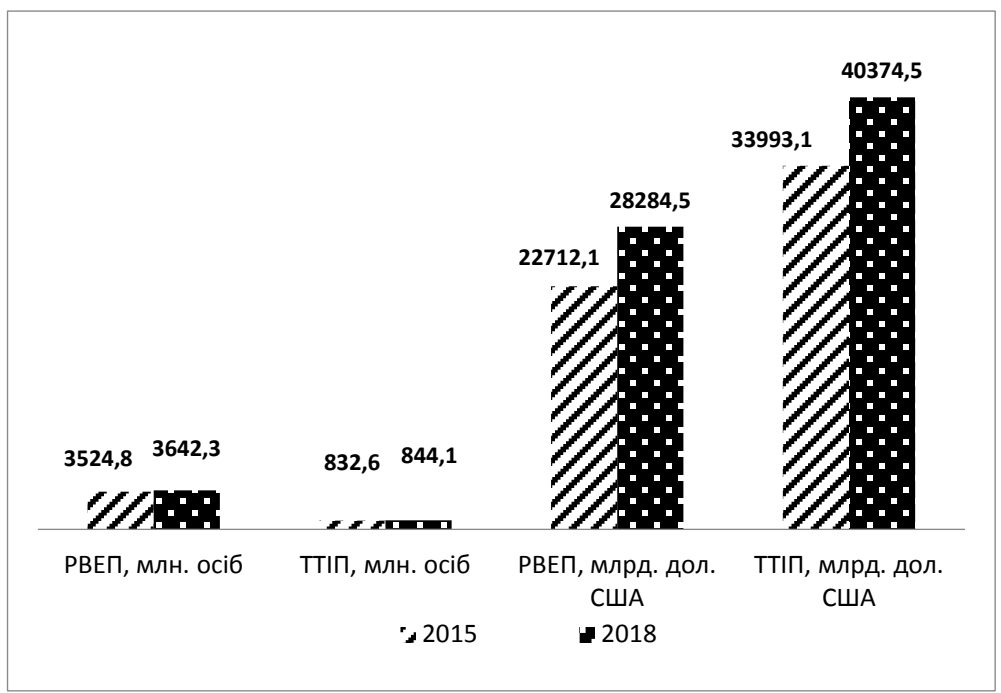

Рис. 3. Співставлення чисельності населення i ВВП РВЕП і ТТIП у 2015 та 2018 pp.

Джерело: складено автором за [21; 24]

у виробництві ВВП досягти рівня ТТІП. Адже, якщо у 2015 р. рівень ВВП ТТІП перевищував рівень ВВП РВЕП на 49,67\%, то у 2018 р. на 42,75\%. Проте якщо досягти рівня виробництва номінального ВВП країнами РВЕП рівня виробництва номінального ВВП ТТІП може стати реальністю, то досягнення ними виробництва ВВП на душу населення ТТІП є набагато проблематичнішим, адже у 2015 р. виробництво ВВП на душу населення ТТІП складало 40825 дол. США, на душу населення РВЕП - 6443,6 дол. США, тобто виробництво ВВП на душу населення РВЕП складало лише $15,78 \%$ виробництва ВВП на душу населення ТТІП.

Важливою характеристикою співставлення РВЕП і ТТІП є їх зовнішньоторговельна діяльність. На рис. 4 і рис. 5 представлено дані експорту та імпорту товарів протягом аналізованого періоду часу.

Наведені дані на рис. 4 і рис. 5 дозволяють продемонструвати однаковий характер зменшення обсягів екпорту й імпорту товарів країнами 
Chapter «Economic sciences»

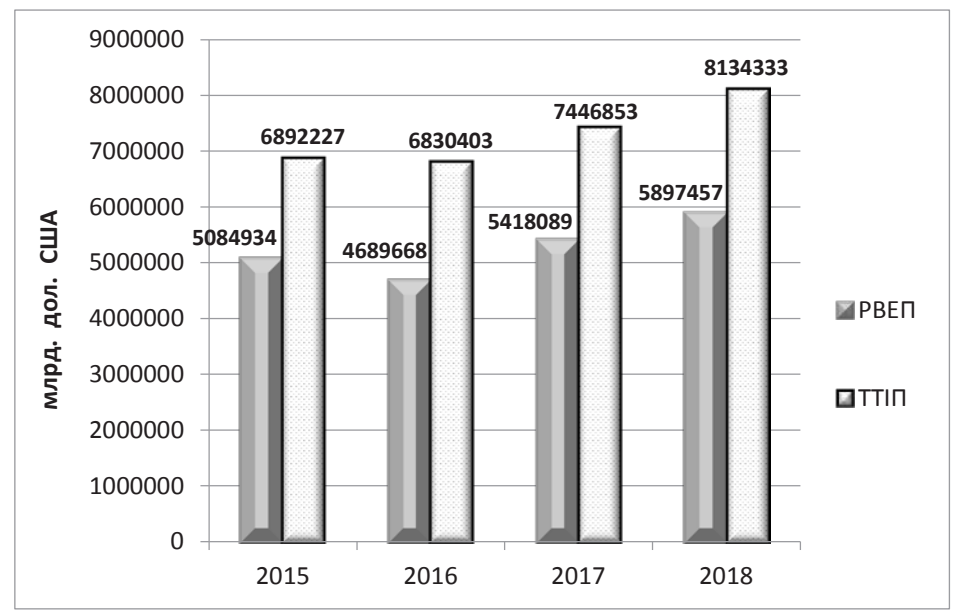

Рис. 4. Експорт товарів РВЕП і ТТІП у 2015-2018 рр., млрд. дол. США Джерело: складено автором за [21-24]

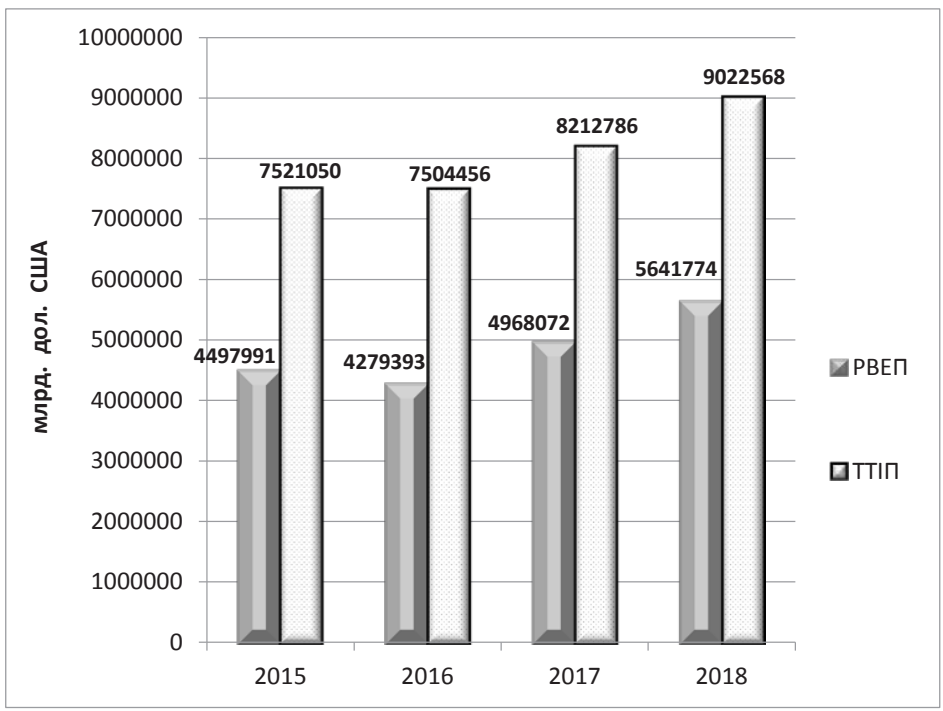

Рис. 5. Імпорт товарів РВЕП і ТТІП у 2015-2018 рр., млрд. дол. США Джерело: складено автором за [21-24] 
РВЕП і ТТІП з 2015 по 2016 рр. та їхнє наступне збільшення. Розрізняється зовнішня торговівля товарами РВЕП і ТТІП тим, що якщо у РВЕП вона має позитивне торговельне сальдо, то у ТТІП - негативне. У 2015 р. позитивне сальдо товарної торгівлі РВЕП становило 586943 млрд. дол. США, у 2018 р. - 255683. Негативне сальдо ТТІП у 2015 р. (-628823), у 2018 р. - (-888235 млрд. дол. США). Отже, спостерігається зменшення позитивного сальдо торгівлі товарами РВЕП і збільшення негативного сальдо торгівлі товарами ТТІП.

Зазначимо, що поки що угоди щодо формування РВЕП і ТТІП не підписані, однак плани щодо прискорення підписання угод залишаються в силі, оскільки у лютому 2020 р. ЄС знову підтвердив свою зацікавленість у розгляді проекту ТТІП, при цьому у листопаді 2019 р. всі країни РВЕП, крім Індії, оголосили завершення узгодження тексту договору, підписання якого заплановано на 2020 рік. Отже, наші розрахунки поки що мають умовний характер.

\section{6. Алгоритм розвитку трансконтинентальних коаліцій}

Основною перевагою укладання трансконтинентальних коаліцій $\epsilon$ можливість іï учасників всебічно обговорювати питання їх розвитку при відсутності будь-яких обмежень щодо кількості учасників і характеру їх участі у переговорах [25]. Алгоритм розвитку трансконтинентальних коаліцій має ставити за мету поступове об'єднання існуючих та підключення нових коаліцій, результатом якого є збільшення кількості учасників переговорів й поглиблення предмету переговорів. Виходячи із існуючої ситуації в основу цього алгоритму слід покласти коаліції, результатом дії яких посилюються зв'язки між провідними країнами, об'єднаннями та міжнародними організаціями. 3 нашої точки зору, логічною є така послідовність дій.

- Забезпечення функціонування ТТІП, яке закладає основи переговорів між країнами та об'єднаннями Західної Європи і Північної Америки;

- Приєднання до функціонування ТТІП існуючих трансконтинентальних партнерств ТТП, ЗВТ ЄС-Канада, СС-Японія. Особливого значення у такій послідовності має посилення ролі у цих зв'язках США, ЄС-28 та Японії;

- Завершення переговорів щодо утворення транконтинентальних ЗВТ ЄС-МЕРКОСУР та ЄС-АСЕАН, об’єднання цих коаліцій з партнер- 
ством РВЕП, завершення укладання коаліції приєднанням до неї міжнародної організації саміту АCЕМ, основною функцією якої є узгодження розвитку країн Азії та Свропи, завдяки чому ії підключення до розглянутих вище трансконтинентальних коаліцій посилить можливості знаходження ними оптимального режиму їх розвитку, що дозволить достатньо широко і глибоко включити у процеси узгодження інтересів країни, об'єднання і організації Європи, Азії та Північної і Латинської Америки;

- Поширення ЮСМКА на Латинську Америку розвитком зв'язків 3 Тихоокеанським альянсом;

- Посилення спрямованості трансконтинентальних коаліцій Латинської Америки на Північну Америку та СС-28;

- Поглиблення дослідження утворення трансконтинентальних коаліцій Африки з СС-28 та Північною Америкою;

- Узгодження розвитку трансконтинентальних коаліцій з реалізацією трансконтинентальної мережі «Один пояс, один шлях».

Основним результатом роботи є визначення широких можливостей використання трансконтинентальних коаліцій для забезпечення узгодженого перебігу процесів регіоналізації та глобалізації, що дозволить підвищити рівень глобального управління світовим господарством і розв'язати суперечності, які виникають на сучасному етапі його розвитку. Аналіз сучасного стану розвитку міжнародних економічних відносин дає можливість дійти висновку, що знайти вихід з тих суперечностей, які утворилися, можна лише на основі запровадження складної системи переговорів і угод з широкою участю великої кількості учасників, що може бути забезпечено формуванням на трансрегіональному рівні структури світового господарства системи трансконтинентальних коаліцій, здатних забезпечити досягнення консолідованого розвитку світового господарства. Зокрема про це свідчить досвід взаємовідносин, які склалися між США та КНР у зв'язку з намірами США запроваджувати протекціоністську політику у міжнародній торгівлі, а КНР демонструє прихільність до ліберальної політики у торгівлі, США посилюють долар, КНР - юань. Отже, знайти компроміс у вирішенні таких суперечностей реально лише на основі домовленостей, провадити які і надає зміцнення ролі у світовому господарстві трансрегіонального рівня його структури шляхом утворення трансконтинентальних коаліцій, враховуючих інтереси усіх їх учасників. 
Перспективним напрямом подальших досліджень слід вважати виявлення факторів формування нових трансконтинентальних коаліцій у світовому господарстві та дослідження їх впливів на взаємовідносини між провідними країнами й об'єднанням світової економіки.

Новизною роботи є пропозиція використання запропонованого поняття трансконтинентальної коаліції для забезпечення узгодженого розвитку світового господарства у вигляді алгоритму формування системи трансконтинентальних коаліцій. В основу алгоритму пропонується закласти принцип поетапного об'єднання трансконтинентальних коаліцій і поступового посилення на його основі узгодженості їх розвитку.

\section{Список літератури:}

1. Ruland J. The European Union as an inter- and transregional actor: lessons for global governance from Europe's relations with Asia, National Europe Centre Paper № 13, 2002. 9 p.

2. Hänggi H. Interregionalism: empirical and theoretical perspectives / Workshop Paper for the Conference "Dollar, Democracy and Trade: External influence on economic integration in the Americas". CA, Los Angeles, May 18, 2000. URL: http:www.cap.lmu.de/transatlantic/download/Haenggi.pdf

3. Gardini G.L., Malamud A. Debunking interregionalism: concepts, types, critique - with a transatlantic focus // Atlantic Future Working Paper, 2015, № 38.23 p.

4. Lai S.Y. Inter-regionalism of nation-states: Asia-Europe Meeting (ASEM) as a case-study. University of Canterbury. National Centre for Research on Europe. 2012. 384 p. URL: http://ir.canterbury.ac.nz

5. Song W. Regionalisation, inter-regional cooperation and global governance // Asia-Europe Journal, February 2007. Vol. 5. P. 67-82.

6. Hänggi $\mathrm{H}$. Interregionalism as a multifaceted phenomenon: in search of a typology // Interregionalism and international relations: a stepping stone to global governance? / Ed. By H. Hänggi, R. Roloff, J. Ruland. N.Y.-L.: Routledge, 2008. 388 p.

7. Maull H.W., Okfen N. Inter-regionalism in international relations: Comparing APEC and ASEM // Asia Europe Journal, 1, May 2003. P. 237-249.

8. Кузнецов Д.А. Феномен трансрегионализма: проблемы терминологии и концептуализации // Сравнительная политика. 2016. № 2(23). С. 14-25.

9. Dent Ch.M. The Asia-Europe meeting and inter-regionalism: toward a theory of multilateral unity // Asian Survey, Vol. 44, No. 2. March/April 2004. P. 213-236. URL: http://as.ucpress.edu

10. Chen Zh. NATO, APEC and ASEM: triadic interregionalism and global order // Asia Europe Journal, 3, 2005. P. 361-378.

11. Rủland J. Interregionalism and international relations: reanimating an obsolescent research agenda? // Intersecting interregionalism. United Nations University Series on Regionalism. Vol. 7. Springer. Dordrecht. 2014. P. 15-35.

12. Doidge M. Joined at the hip: regionalism and interregionalism. Vol. 29, 2007. Issue 2. P. 229-248. 
13. Корінець Г.Б., Флейчук М.І., Львівська К.А. Значення Українсько-азійської співпраці в умовах посилення глобалізаційних процесів // Науковий вісник Національного лісотехнічного університету України. 2011. Вип. 21.9. С. 367-372.

14. Asia-Pacific Economic Cooperation. StatsAPEC, Key indicators database. URL: http://statistics.apec.org/index.php/apec_psu/index_noflash

15. The Translatlantic Trade and Investment Partnership. European Commission. URL: https://ec.europa.eu

16. Borrell's first visit to the US: stepping up the transatlantic partnership in challenging times, European Commission. URL: https://ec.europa.eu

17. Eder T.S. Mapping the Belt and Road initiative: this is where we stand. 7 June 2018. MERCATOR Institute for China Studies. URL: https://www.merics.org/ en/bri-tracker/mapping-the-belt-and-road-initiative

18. Хейфец Б.А. Трансрегиональное переформатирование глобального экономического пространства. Москва : Институт экономики РАН, 2016. 86 с.

19. Розвиток новітніх форм міжнародної економічної інтеграції на початку XXI століття: монографія / O.I. Шнирков, А.С. Філіпенко, Р.О. Заблоцька та ін.; за ред. О.І. Шниркова. Київ : ВПЦ “Київський університет”, 2016. 415 с.

20. China's Foreign Affairs 2019. Department of Policy Planning. Ministry of Foreign Affairs of the People's Republic of China. 2019. 360 p.

21. UNCTAD Handbook of Statistics 2016. United Nations. N. Y. \& Geneva, 2017.

22. UNCTAD Handbook of Statistics 2017. United Nations. N. Y. \& Geneva, 2018.

23. UNCTAD Handbook of Statistics 2018. United Nations. N. Y. \& Geneva, 2019.

24. UNCTAD Handbook of Statistics 2019. United Nations. N. Y. \& Geneva, 2020.

25. Радзієвська С.О. Регіоналізація і глобалізація: взаємозв'язки та перспективи безконфронтаційного розвитку. Київ : “СІК ГРУП УКРАЇНА”, 2018. 376 с.

\section{References:}

1. Rüland J. The European Union as an inter- and transregional actor: lessons for global governance from Europe's relations with Asia, National Europe Centre Paper № 13, 2002. 9 p.

2. Hänggi H. Interregionalism: empirical and theoretical perspectives / Workshop Paper for the Conference "Dollar, Democracy and Trade: External influence on economic integration in the Americas". CA, Los Angeles, May 18, 2000. URL: http://www.cap.lmu.de/transatlantic/download/Haenggi.pdf

3. Gardini G.L., Malamud A. Debunking interregionalism: concepts, types, critique - with a transatlantic focus // Atlantic Future Working Paper, 2015, № 38. 23 p.

4. Lai S.Y. Inter-regionalism of nation-states: Asia-Europe Meeting (ASEM) as a case-study. University of Canterbury. National Centre for Research on Europe. 2012. 384 p. URL: http://ir.canterbury.ac.nz

5. Song W. Regionalisation, inter-regional cooperation and global governance // Asia-Europe Journal, February 2007, Vol. 5. P. 67-82.

6. Hänggi H. Interregionalism as a multifaceted phenomenon: in search of a typology // Interregionalism and international relations: a stepping stone to global governance? / Ed. By H. Hänggi, R. Roloff, J. Ruland. N.Y.-L.: Routledge, 2008. 388 p. 
7. Maull H.W., Okfen N. Inter-regionalism in international relations: Comparing APEC and ASEM // Asia Europe Journal, 1, May 2003. P. 237-249.

8. Kuznetsov D.A. Phenomen transregionalisma: problemy terminologii i kontseptualizatsii [Transregionalism: problems of terminology and conceptualization]. Comparative politics. 2016. 2(23). P. 14-25.

9. Dent Ch.M. The Asia-Europe meeting and inter-regionalism: toward a theory of multilateral unity // Asian Survey, Vol. 44, No. 2. March / April 2004. P. 213-236. URL: http://as.ucpress.edu

10. Chen Zh. NATO, APEC and ASEM: triadic interregionalism and global order//Asia Europe Journal, 3, 2005. P. 361-378.

11. Rủland J. Interregionalism and international relations: reanimating an obsolescent research agenda? // Intersecting interregionalism. United Nations University Series on Regionalism. Vol. 7. Springer. Dordrecht. 2014. P. 15-35.

12. Doidge M. Joined at the hip: regionalism and interregionalism. Vol. 29, 2007. Issue 2. P. 229-248.

13. Korinets G.B., Fleychuk M.I., Lvivska K.A. Znachennya Ukrainsko-aziyskoi spivpratsi $\mathrm{v}$ umovakh posylennya globalizatsiynykh protsesiv [The role of UkraineAsia cooperation in the conditions of globalization processes strengthening]. Scientific bulletin of the National Forestry University of Ukraine. 2011. Vol. 21.9. P. 367-372.

14. Asia-Pacific Economic Cooperation. StatsAPEC, Key indicators database. URL: http://statistics.apec.org/index.php/apec_psu/index_noflash

15. The Translatlantic Trade and Investment Partnership. European Commission. URL: https://ec.europa.eu

16. Borrell's first visit to the US: stepping up the transatlantic partnership in challenging times, European Commission. URL: https://ec.europa.eu

17. Eder T.S. Mapping the Belt and Road initiative: this is where we stand. 7 June 2018. MERCATOR Institute for China Studies. Available at: https://www.merics.org/en/bri-tracker/mapping-the-belt-and-road-initiative

18. Kheyfets B.A. Transregionalnoye pereformatirovaniye globalnogo ekonomicheskogo prostranstva [Transregional reformation of the global economic space]. Moscow. Institute of economy, 2016. 86 p.

19. Zhnyrkov O.I., Filipenko A.S., Zablotska R.O. Rozvytok novitnikh form mizhnarodnoyi ekonomichnoyi integratsii na pochatku 21 stolittya [Development of the new international integration forms in the beginning of the 21st century]. Kyiv: Kyiv National University, 2016. 415 p.

20. China's Foreign Affairs 2019. Department of Policy Planning. Ministry of Foreign Affairs of the People's Republic of China. 2019. 360 p.

21. UNCTAD Handbook of Statistics 2016. United Nations. N. Y. \& Geneva, 2017.

22. UNCTAD Handbook of Statistics 2017. United Nations. N. Y. \& Geneva, 2018.

23. UNCTAD Handbook of Statistics 2018. United Nations. N. Y. \& Geneva, 2019.

24. UNCTAD Handbook of Statistics 2019. United Nations. N. Y. \& Geneva, 2020.

25. Radziyevska S.O. (2018) Regionalizatsiya i globalizatsiya: vzayemozvyazky ta perspektivy bezkonfrontatsiynogo rozvytku [Regionalization and globalization: interrelations and prospects for non-confrontational development]. Kyiv: Sik Group Ukraine, 376 p. 